\title{
THEORETICAL AND EXPERIMENTAL STUDIES OF THE CORROSION BEHAVIOR OF SOME THIAZOLE DERIVATIVES TOWARD MILD STEEL IN SULFURIC ACID MEDIA
}

\author{
Avni Berisha*, Fetah I. Podvorica*, Valbonë Mehmeti, Fidan Syla, Debatik Vataj \\ Department of Chemistry, Faculty of Natural Sciences and Mathematics, University of Prishtina, \\ Rr. "NënaTerezë" nr. 5, 10 000, Prishtina, Republic of Kosovo \\ fetah.podvorica@uni-pr.edu, avni.berisha@uni-pr.edu
}

\begin{abstract}
The corrosion behavior of iron in diluted aqueous sulfuric acid medium has been studied in the presence and absence of 6-ethoxybenzo[d]thiazol-2-amine (EBT), 5-bromothiazol-2-amine (BTA) and 4,5-dimethylthiazol-2-amine (DTA). Potentiodynamic measurements showed the shift of corrosion potential towards a more negative potential indicating that these compounds mostly act as cathodic inhibitors due to their adsorption on the iron surface. The adsorbed film of these molecules hinders the transport of metal ions from the metal to the solution and also retards hydrogen evolution reaction by acting as a physical barrier. The molecules were also studied by density functional theory (DFT), using the B3LYP functional in order to determine the relationship between molecular structure and the corrosion inhibition efficiencies.
\end{abstract}

Keywords: corrosion inhibition; cathodic inhibitors; thiazole derivatives;

potentiodynamic measurements

\section{ТЕОРЕТСКА И ЕКСПЕРИМЕНТАЛНА СТУДИЈА ЗА КОРОЗИВНО ОДНЕСУВАЊЕ НА НЕКОИ ТИЗАОЛНИ ДЕРИВАТИ КОН МЕК ЧЕЛИК ВО МЕДИУМ НА СУЛФУРНА КИСЕЛИНА}

\begin{abstract}
Корозивното однесување на железото во медиум на разредена со вода сулфурна киселина беше студирано во присуство и отсуство на 6-етоксибензо[d]тиазол-2-амин (EBT), 5-бромотиазол2-амин (BTA) и 4,5-диметилтиазол-2-амин (DTA). Потенциодинамичките мерења покажаа поместување на потенцијалот на корозија кон понегативен потенцијал, што укажува дека овие соединенија во основа се однесуваат како катодни инхибитори поради нивната атсорпција на површината на железото. Атсорбираниот филм на овие молекули го спречува преносот на метални јони од металот во растворот, а исто така ја забавува реакцијата на издвојување на водород бидејќ дејствува како физичка бариера. Молекулите беа исто така студирани со теоријата на густина на функционалот (DFT) со употреба на функционалот B3LYP за да се определи зависноста меѓу молекулската структура и ефикасноста на инхибиција на корозијата.
\end{abstract}

Клучни зборови: инхибиција на корозија; катодни инхибитори; деривати на тиазол; потенциодинамички мерења

\section{INTRODUCTION}

Coinage metals are oxidized easily in aggressive solutions during industrial cleaning and different treatments such as acid pickling, acid descaling and acid cleaning. On a large scale, people use metal coating with paints and polymers in order to reduce the effect of different agents on their surface. The drawback of this procedure is the weak bond between the metal surface and the coating layer [1]. Protection of metals against corrosion in acidic media can also be attained through the 
use of inhibitors which are able to prevent or mitigate the oxidation reaction of the metal [2-4]. These materials can be inorganic or organic substances which, when added at small concentrations in acid solution, interact specifically with the metal surface; for example electrostatic attractions between charged molecules and metal surfaces, interactions of electron-rich atoms in molecules with metal, etc. $[5,6]$. The metal protection can be also achieved through the use of surface modification strategies by chemical or electrochemical methods such SAM's (Self Assembled Monolayers) formed from phosphonic acids [7, 8] or electrochemical reduction of aryldiazonium salts on metals [9], with the exception of 2,6-dimethylbenzene diazonium salt [10]. Once reduced electrochemically or chemically on the surface of the materials, aryl diazonium salts provide very reactive aryl species which react with their surface and form strong attached organic layers. In the case of an iron electrode, the organic films also reveal protective properties, as they diminish the iron corrosion rate in aqueous acid and neutral medium. In addition, different organic heterocyclic compounds have been found to be effective inhibitors for steel in different corrosive media [11]. The electron density of the molecule depends on the existing functional group in the molecules such as heteroatoms (e.g., N, O, S and P), aromatic rings and others [12-15]. Molecules with high electron density are prone to coordinating to a greater extent with the metal surface, thereby acting as efficient corrosion inhibitors $[16,17]$. Thiazole derivatives are considered non-cytotoxic substances, with the potential to replace other toxic organic inhibitors used for the corrosion protection of metals.

Quantum chemical methods are frequently utilized to clarify the physicochemical properties of the molecules of interest in order to understand their interaction with the metal surface and to define the centers in the molecules which are respon- sible for such interactions [12, 18, 19]. In this work, density functional theory is applied to obtain some molecular properties of 6-ethoxybenzo [d]thiazol-2-amine (EBT), 5-bromothiazol-2-amine (BTA) and 4,5-dimethylthiazol-2-amine (DTA) and to investigate the possible relationship between those computed molecular properties with the corrosion inhibition efficiencies of these molecules.

\section{EXPERIMENTAL SECTION}

The electrodes were made of commercial 316 stainless steel. For electrochemical measurements, wires with $0.55 \mathrm{~cm}^{2}$ surface were used. The steel surface was mechanically polished with emery paper, cleaned with distilled water and degreased in ethanol, washed with distilled water and finally dried in air.

The polarization studies were carried out in $0.001 \mathrm{M}$ sulfuric acid using a computer-controlled PalmSens potentiostat and employing a three electrode cell assembly. A saturated calomel electrode (SCE) and platinum electrode were used as the reference and auxiliary electrodes, respectively. All solutions were prepared from analytic grade chemicals and bidistilled water.

\subsection{Computational details}

The calculations presented below were done by using Functional Theory (DFT) method with the B3LYP functional using the 6-31G(d,p). Molecular parameters like electronegativity, global hardness and softness, electron affinity and ionization potential may be defined in relationships of the energy of the HOMO and the LUMO which can be calculated, in a reproducible manner, by the DFT/B3LYP method [17, 20]. The mentioned parameters, their meaning and the equations from which they can be calculated are presented in the table below:

\begin{tabular}{lll}
\hline \hline Formula & Meaning & Ref \\
\hline$X \approx-1 / 2\left(E_{\mathrm{HOMO}}+E_{\mathrm{LUMO}}\right)$ & $\begin{array}{l}\text { Electronegativity }(X) \text { is the value of the power of an electron or group of } \\
\text { atoms to attract electrons towards itself }\end{array}$ & {$[21]$} \\
$\eta \approx-1 / 2\left(E_{\mathrm{HOMO}}-E_{\mathrm{LUMO}}\right)$ & $\begin{array}{l}\text { Chemical hardness }(\eta) \text { is the value of the resistance of an atom to a charge } \\
\text { transfer }\end{array}$ & {$[22]$} \\
$\sigma \approx 1 / \eta=-2\left(E_{\mathrm{HOMO}}-E_{\mathrm{LUMO}}\right)$ & $\begin{array}{l}\text { Chemical softness }(\sigma) \text { is the measure of the capacity of an atom or group } \\
\text { of atoms to receive electrons } \\
I \approx-E_{\mathrm{HOMO}}\end{array}$ & $\begin{array}{l}\text { Ionization potential }(I) \text { is defined as the amount of energy required to re- } \\
\text { move an electron from a molecule } \\
A \approx-E_{\mathrm{LUMO}}\end{array}$ \\
\hline \hline
\end{tabular}




\section{RESULTS AND DISCUSSION}

\subsection{Potentiodynamic polarization}

The anodic and cathodic polarization curves of a mild steel electrode in aqueous $0.001 \mathrm{M}$ $\mathrm{H}_{2} \mathrm{SO}_{4}$ in the absence and presence of various heterocyclic compounds at $25^{\circ} \mathrm{C}$ are shown in Figure 1. One can observe in all of these semi-logarithmic polarization curves that in the presence of DTA, EBT and BTA molecules, the decrease of anodic and cathodic current indicates that the oxidation of the iron and the proton discharge are slowed down.
This protection is attributed to the adsorption of the inhibitor over the corroded metal surface [24, 25]. Since both anodic dissolution of iron and hydrogen evolution were suppressed, the studied molecules behave like a mixed inhibitor [26].

Polarization resistances of $\mathrm{Fe}$ electrodes without and in the presence of the inhibitors EBT, BTA and DTA are measured when the electrode potential is swept over a small range from $E_{\text {corr }}( \pm$ $10 \mathrm{mV}$, which does not affect the natural corrosion process). These results are shown in Figure 2 and their values are given in Table 1.
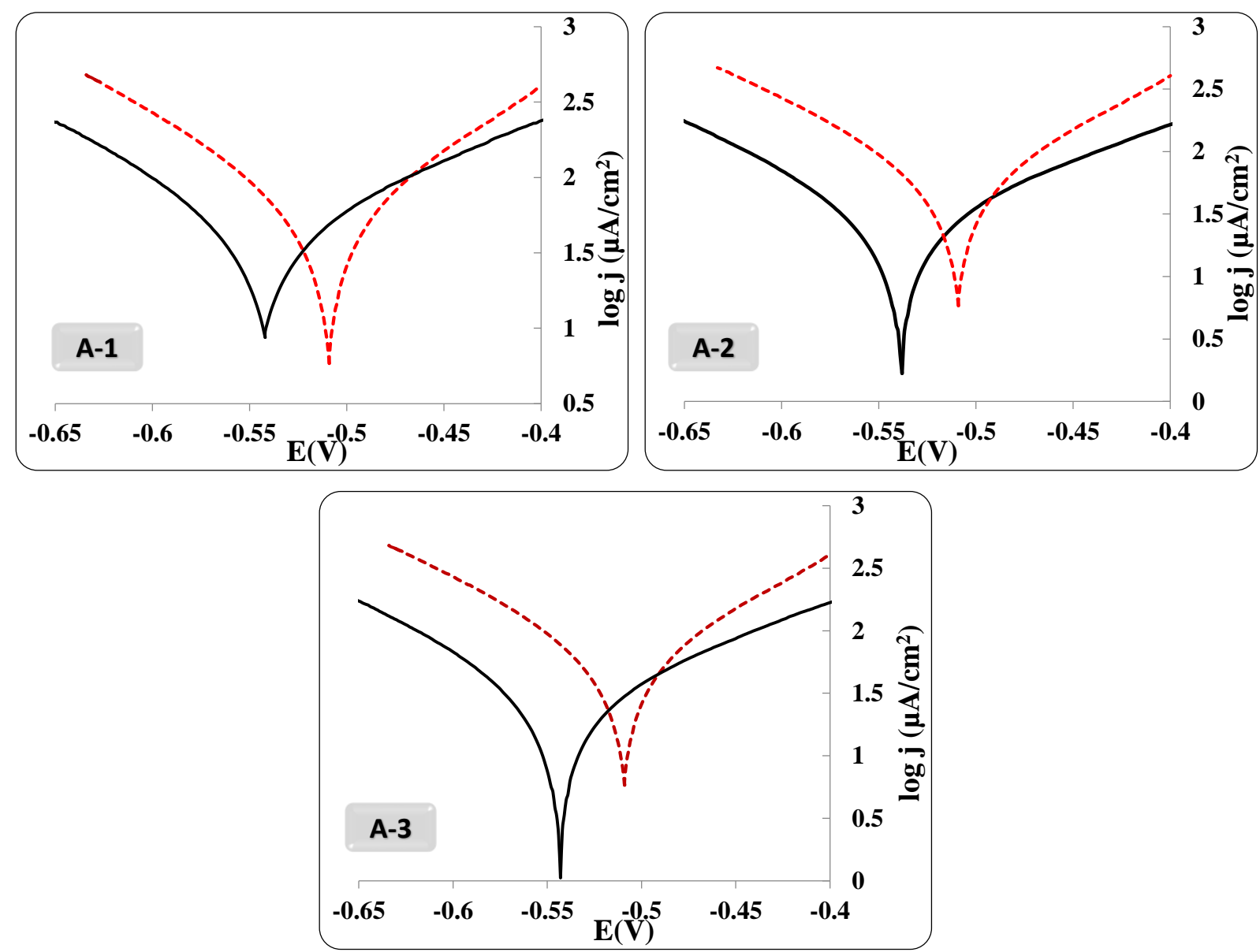

Fig. 1. Polarization curve for mild steel in $0.001 \mathrm{M} \mathrm{H}_{2} \mathrm{SO}_{4}$ in the presence (line) and absence (red dashed line) of: A-1. 4,5-dimethylthiazol-2-amine; A-2. 5-bromothiazol-2-amine; A-3. $5 \mathrm{mM}$ 6-ethoxybenzo[ $d]$ thiazol-2-amine (red dashed line) at a scan rate of $1 \mathrm{mV} / \mathrm{s}$ (measured at $25^{\circ} \mathrm{C}$ ), and an inhibitor concentration $5 \mathrm{mM}$.

The values of associated electrochemical parameters, such as corrosion potential $\left(E_{\text {corr }}\right)$ and corrosion current density $\left(I_{\text {corr }}\right)$, were calculated from the intersection of anodic and cathodic Tafel slopes of the polarization curves and are shown in Table 1 . The IE $(\%)$ was calculated using the following equation:

$$
I E(\%)=\frac{\left(I_{\text {corr }}\right)_{\text {absenceofinhibitor }}-\left(I_{\text {corr }}\right)_{\text {presenceofinhibitor }}}{\left(I_{\text {corr }}\right)_{\text {absenceo finhibitor }}} \times 100
$$



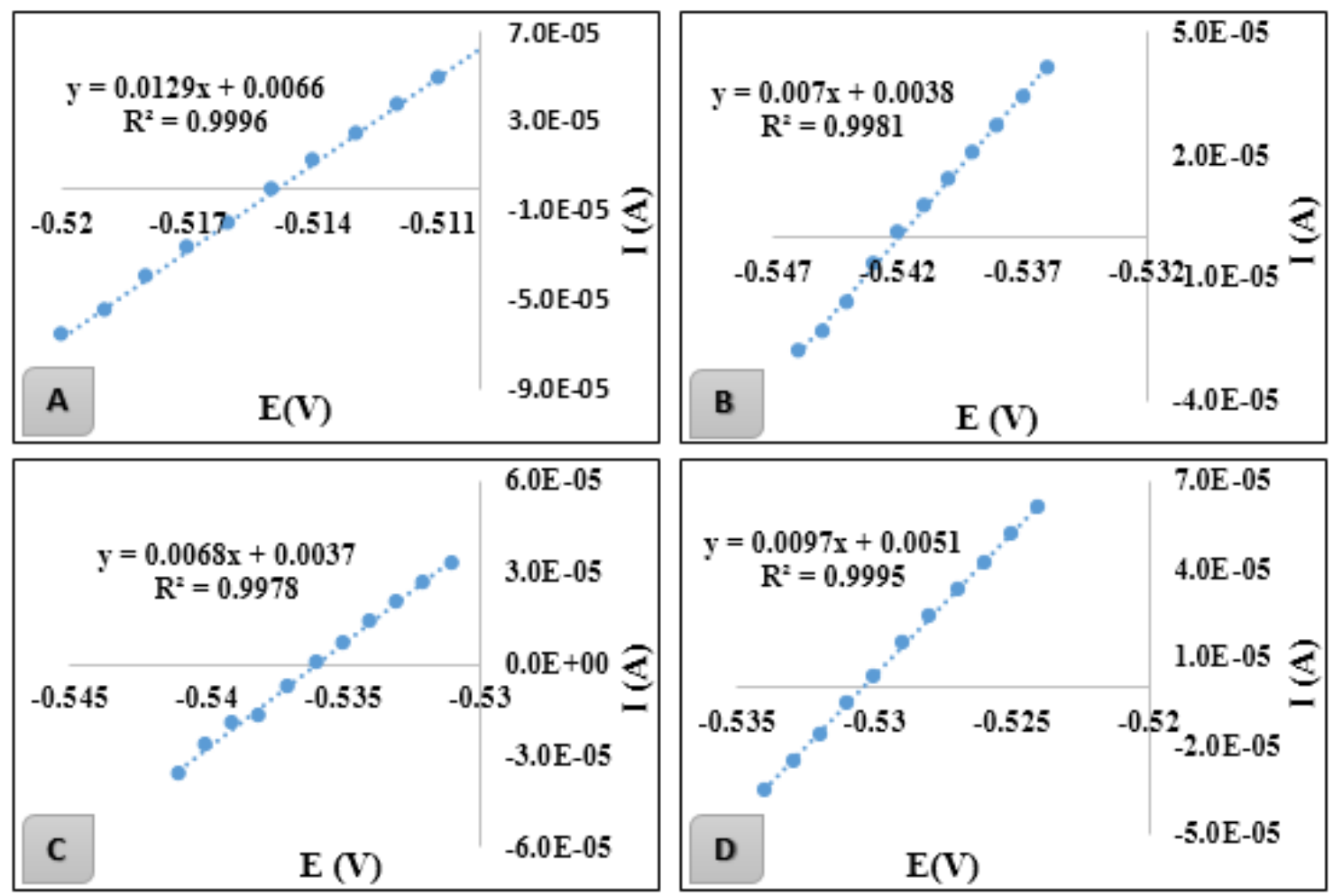

Fig.2. Polarization resistance measurements of Fe electrode in $0.001 \mathrm{M}$ sulfuric acid: A. Fe electrode; B to D in the presence of $5 \mathrm{mM}$ solutions of EBT, BTA and DTA.

Table 1

The chemical structure of the investigated compounds, their inhibition efficiency and polarization resistance values (Fe electrode, $0.001 \mathrm{M} \mathrm{H}_{2} \mathrm{SO}_{4}+5 \mathrm{mM}$ of the corresponding inhibitor molecule).

\begin{tabular}{l}
\hline Compound name and structure \\
6-ethoxybenzo[d]thiazol-2-amine (EBT) \\
5-bromothiazol-2-amine (BTA) \\
48.03 \\
$\begin{array}{l}\text { Polarization resistance }(\mathrm{RP}, \text { in } \Omega) \\
\text { For iron } R P=77.519 \\
142.857\end{array}$
\end{tabular}

The optimized geometries of the studied compounds are shown in Figure 3 together with the Mulliken charges population at the so called frontier orbitals HOMO and LUMO.

The shape and symmetry of HOMO and LUMO are the main parameters for estimating the reactivity of a molecule as well as estimating the course of chemical reactions $[12,27]$. The analysis of HOMO indicates the regions of the molecule that have a tendency to donate electrons to electrophilic species while the analysis of LUMO predicts the regions of the molecule with a high tendency to accept electrons from nucleophilic species. Ionization potential is directly related to the energy of the HOMO orbital and the electron affinity is dependent on the energy of the LUMO orbital. Our results show that HOMO and LUMO are delocalized throughout the molecules of the selected compounds. 


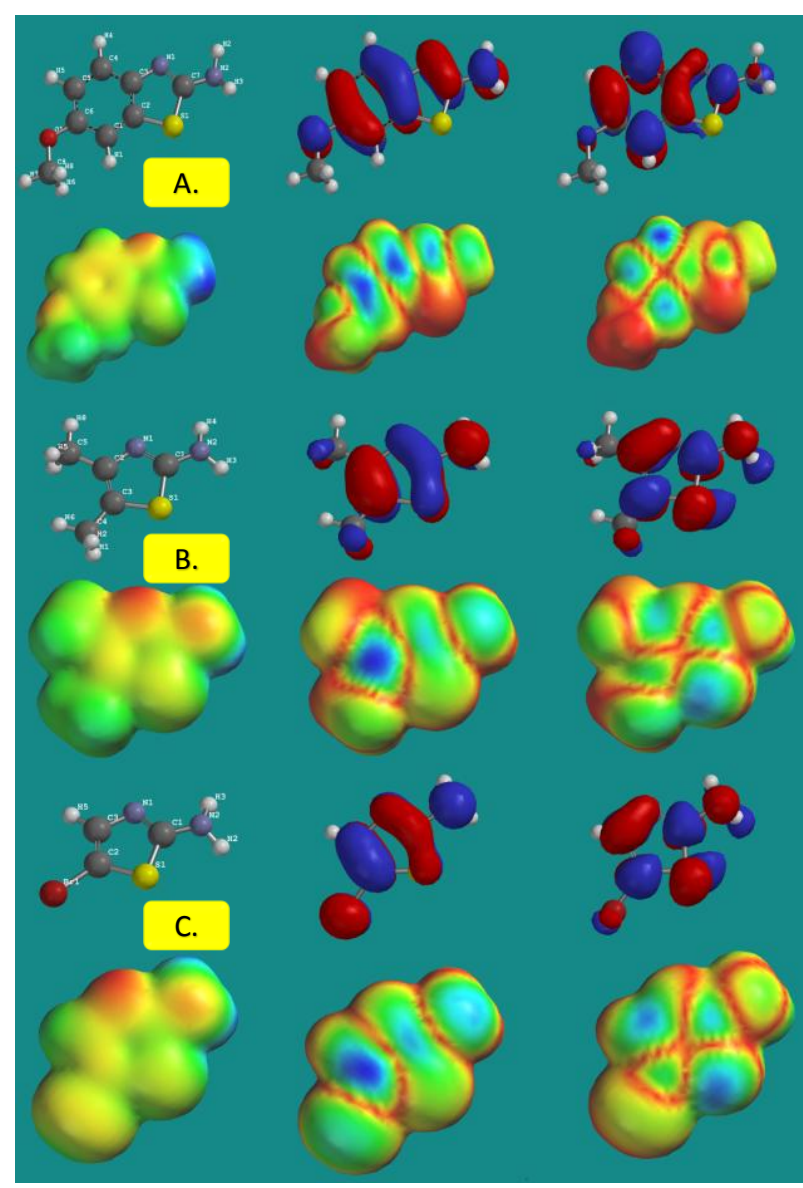

Fig. 3. Optimized structures: A. HOMO, B. HOMO density, C. LUMO, and D. LUMO density for the studied compounds: A. Amino-6-thoxybenzothiazole; B. 2-amino-4,5-dimethylthiazole, C. 2-amino-5-bromothiazole. (B3LYP/6-31G (d,p) results in vacuo).

In EBT, the HOMO orbital has the highest distribution on the $\mathrm{C} 5=\mathrm{C} 6$ and $\mathrm{C} 3=\mathrm{C} 4$ double bonds and at nitrogen atoms at $\mathrm{N} 1=\mathrm{C} 7$ and $\mathrm{N} 2$, which implies that these are the regions of the molecule with the highest tendency to donate electrons; LUMO is strongly localized on the $\mathrm{C} 11$ atom. In the BTA molecule, the HOMO orbital is spread in the region between the $\mathrm{C} 2=\mathrm{C} 3$ (greater extent) and $\mathrm{C} 1=\mathrm{N} 1$ (less extent) double bonds and at the nitrogen atom at N2; LUMO is strongly localized between the ring atoms. In DTA, the HOMO orbital is spread in the region between the $\mathrm{C} 2=\mathrm{C} 3$ double bond; LUMO is spread out on almost all atoms of the aromatic rings between $\mathrm{S} 1$ C1-N2 atoms.

We have also calculated the molecular volume (MV) of three studied compounds. Molecular volume governs the surface coverage of the inhibitor on the metal surface. The compound that would have the highest surface coverage of the metal typically corresponds to that with the greatest inhibition efficiency. A comparison of the MV values across structures show the order EBT $>$ DTA $>$ BTA. Therefore, the expected order of inhibition efficiency would favorably be such that EBT $>$ DTA $>$ BTA, which is not the case with experimentally obtained inhibition efficiency for these compounds. The properties influencing the reactivity of the compound include the energy of HOMO $\left(E_{\mathrm{HOMO}}\right)$, the energy of LUMO ( $\left.E_{\mathrm{LUMO}}\right)$, the energy difference between HOMO and LUMO $(\Delta E)$, global hardness $(\eta)$, global softness $(\sigma)$ and the dipole moment $(\mu)$, etc. These parameters are reported in Table 2.

As mentioned before, the energy of HOMO shows the capability of the molecule to donate electrons $[12,17,28]$. The molecule with the higher $\mathrm{E}_{\mathrm{HOMO}}$ has electrons with higher energy and therefore it can easily share these electrons with other species. In the investigated compounds, the order of the $\mathrm{E}_{\mathrm{HOMO}}$ is $\mathrm{BTA}>\mathrm{EBT}>\mathrm{DTA}$; consequently, $\mathrm{BTA}$ should have the highest tendency to adsorb onto the metal surface and provide electrons the lone pair electrons on $\mathrm{S}$ and $\mathrm{N}$ atoms to the unoccupied iron d-orbital $[29,30]$. This trend agrees very well with experimentally determined inhibition efficiencies. A negative value for $E_{\mathrm{HOMO}}$ indicates physical adsorption of the organic molecule [31].

Table 2

The molecular properties for the investigated compounds using: DFT, B3LYP/6-31G $(d, p)$. Results in vacuo. All energies are in $\mathrm{eV}$.

\begin{tabular}{lcccccccccc}
\hline \hline Structure & $\mathrm{E}_{\text {НОмО }}$ & $\mathrm{E}_{\text {LUMO }}$ & $\Delta \mathrm{E}$ & $\mathrm{MV}$ & $\mu$ & $\mathrm{IP}$ & $\mathrm{A}$ & $\chi$ & $\eta$ & $\sigma$ \\
\hline EBT & -5.24 & -0.08 & 5.160 & 168.23 & 2.81 & 5.24 & 0.08 & 2.66 & 2.58 & 0.388 \\
BTA & -5.64 & -0.30 & 5.340 & 107.64 & 2.81 & 5.64 & 0.30 & 2.97 & 2.67 & 0.375 \\
DTA & -5.09 & -0.21 & 5.300 & 126.26 & 1.47 & 5.09 & 0.21 & 2.44 & 2.65 & 0.377 \\
\hline \hline
\end{tabular}

The energy of LUMO shows the tendency of the molecule to accept electrons from an electronrich species. The molecule with the lowest energy of LUMO has the highest tendency to accept electrons. The trend in $E_{\mathrm{LUMO}}$ for the calculated compounds is such that BTA $<$ DTA $<$ EBT, which 
implies that BTA would preferentially accept electrons from the metal surface.

The trend in the $E_{\mathrm{LUMO}}$, however, does not also correlate well with the trend in the experimentally determined inhibition efficiency.

The energy difference between the $E_{\mathrm{HOMO}}$ and the $E_{\mathrm{LUMO}}, \Delta E$, tells about the reactivity of the molecule towards other chemical species. The molecule with the lowest $\Delta E$ value has the highest tendency towards reactivity and would favorably interact with the metal surface. A comparison of the $\Delta E$ values of the studied compounds shows that the trend is such that EBT $<$ DTA $<$ BTA. This trend also does not correlate well with the trend in the experimentally determined inhibition efficiencies.

The global hardness and softness parameters are frequently discussed in terms of hard-soft-acidbase (HSAB) theory. According to this theory, soft acids interact preferentially with soft bases and hard ones with hard bases. Metals are generally considered to be soft acids [32]; therefore, they would preferentially interact with inhibitors that have high $\sigma$ values and low $\eta$ values. The $\sigma$ values for the investigated compounds follow the trend EBT $<$ BTA $<$ DTA, which is not in good agreement with experimentally determined inhibition efficiency of the inhibitors. The dipole moment tells about the polarity of the molecule. Numerous re- searchers in the area of corrosion science have established that an increase in the inhibition efficiency is related to the increase in the dipole moment [28]. The order of the dipole moment for the studied compounds is such that BTA $\approx$ EBT $>$ DTA. This trend correlates well with experimentally determined inhibition efficiency.

Some molecular properties apart the reactivity of molecules also indicate the site selectivity in an individual chemical species, i.e., the regions of the molecules on which certain type of reactions are likely to occur. The partial atomic charge on the atoms of the molecule is one of these parameters. The interaction between the metal and the inhibitor is often considered to preferentially take place on the atom with the highest negative charge [33]. The Mulliken atomic charges for the studied compounds are reported in Table 3 and the highest negative charge on all the molecules is located on the heteroatoms, which suggests that these centers have the highest electron density and would preferentially interact with the metal surface. This is in agreement with the results obtained by Maniavel et al. [34], which showed that inhibitor properties of $(S)-4,5,6,7$-tetrahydrobenzo[ $d]$ thiazole-2,6-diamine (TDA) molecule on the iron surface were due to the electrostatic attraction between heteroatom in the TDA and iron surface.

\section{T a ble 3}

\section{Mulliken atomic charges on the atom of the investigated compounds (B3LYP/6-31G d,p)} results in vacuo

\begin{tabular}{lccccr}
\hline \hline Atom & $\begin{array}{c}\text { EBT } \\
\text { Mulliken } \\
\text { atomic charge }\end{array}$ & Atom & $\begin{array}{c}\text { BTA } \\
\text { Mulliken } \\
\text { atomic charge }\end{array}$ & Atom & $\begin{array}{c}\text { DTA } \\
\text { Mulliken } \\
\text { atomic } \\
\text { charge }\end{array}$ \\
\hline C1 & -0.255 & $\mathbf{C 1}$ & 0.287 & $\mathbf{C 1}$ & 0.293 \\
C2 & -0.134 & $\mathbf{C 2}$ & -0.238 & $\mathbf{C 2}$ & 0.296 \\
C3 & 0.293 & $\mathbf{C 3}$ & 0.051 & $\mathbf{C 3}$ & -0.153 \\
$\mathbf{C 4}$ & -0.161 & $\mathbf{S 1}$ & 0.257 & $\mathbf{C 4}$ & -0.509 \\
$\mathbf{C 5}$ & -0.192 & $\mathbf{N 1}$ & -0.444 & $\mathbf{S 1}$ & 0.183 \\
C6 & 0.390 & $\mathbf{N 2}$ & -0.743 & $\mathbf{N 1}$ & -0.493 \\
$\mathbf{C 7}$ & 0.306 & $\mathbf{B r 1}$ & -0.027 & $\mathbf{N 2}$ & -0.751 \\
$\mathbf{C 8}$ & -0.214 & & & & \\
$\mathbf{N 1}$ & -0.526 & & & & \\
N2 & -0.757 & & & & \\
O1 & -0.511 & & & & \\
\hline \hline
\end{tabular}

\section{CONCLUSIONS}

The inhibition efficiency of: 6-ethoxybenzo [d] thiazol-2-amine (EBT), 5-bromothiazol-2-amine (BTA) and 4,5-dimethylthiazol-2-amine (DTA) has been investigated by experimental techniques and quantum chemical approaches. Potentiodynamic measurements put in evidence the inhibitor properties of these thiazole derivatives toward ion corrosion in aqueous acid medium. The quantum chemical calculations revealed information about the active centers (of the compounds) which would 
likely interact with the metal surface. The analysis of the HOMO and LUMO orbital energies showed the possible electron donating centers on the inhibitor molecules and this tendency is also confirmed by calculating charges on the atoms. Experimental and theoretical results show that the inhibition efficiencies are highest for thiazole rings that contain extra hetero atoms apart that of the thiazole ring; these values are in good agreement with the calculated Mülliken charges, which impose that these atoms are more prone to adsorb on the iron surface and thus have a greater impact on corrosion inhibition efficiency. $\mathrm{E}_{\text {номо, dipole moment and }}$ Mülliken atomic charges are the parameters which best correlate with the experimental data.

\section{REFERENCES}

[1] R. Plankaert, Surface Coating. In Ullman's Encyclopedia of Industrial Chemistry, $5^{\text {th }}$ Ed.; $\mathrm{VCH}$ : Weinheim, 1994; Vol. A25.

[2] G. Trabanelli, Inhibitors - An Old Remedy for a New Challenge, Corrosion, 47, 410-419 (1991).

[3] P. B. Raja, M. G. Sethuraman, Natural products as corrosion inhibitor for metals in corrosive media, Mater. Lett., 62, 113-116 (2008).

[4] M. Lagrenée, B. Mernari, M. Bouanis, M. Traisnel, F. Bentiss. Corros. Sci., 44, 573-588 (2002).

[5] Y. I. Kuznetsov, Organic Inhibitors of Corrosion of Metals, $1^{\text {st }}$ Edition, Published by Springer, Einbeck, Germany 1996.

[6] M. Ash, I. Ash, Handbook of Corrosion Inhibitors, Synapse Information Resources, Endicott, N.Y., 2011.

[7] G. Gunasekaran, R.Natarajan, V. S. Muralidharan, N. Palaniswamy, B. V. App Rao, Inhibition by phosphonic acids, Anti-Corros. Methods Mater., 44, 248-259 (1997).

[8] J. G. Van Alsten, Self-Assembled Monolayers on Engineering Metals: Structure, Derivatization, and Utility, Langmuir, 15, 7605-7614 (1999).

[9] a) A. Chausse, M. M. Chehimi, J. Pinson, F. Podvorica and C. Vautrin-Ul, The Electrochemical Reduction of Aryldiazonium Salts on Iron electrodes. Their effects on Corrosion, Chem. Mater., 14, 392-400 (2002). b) M. C. Bernard, A. Chausse, E. Deliry, M. M. Chehimi, J. Pinson, F. Podvorica and C. Vautrin-Ul, Organic layers bonded to industrial, coinage and noble metals through electrochemical reduction of aryldiazonium salts, Chem. Mater., 15, 3540-3552 (2003). c) F.I. Podvorica, F. Kanoufi, J. Pinson, C. Combellas, spontaneous grafting of diazoates on metals, Electrochim. Acta, 54, $2164-2170$ (2009). d) A. Berisha, C. Combellas, F. Kanoufi, J. Pinson, S. Ustaze, F. I. Podvorica, Physisorption vs grafting of aryldiazonium salts onto iron: A corrosion study., Electrochim.Acta, 56, 10672-10676 (2011).

[10] a) C. Combellas, De-en Jiang, F. Kanoufi, J. Pinson, and F. I. Podvorica, Steric effects in the reaction of aryl radicals on surfaces, Langmuir, 25, 286-293 (2009), b) A. Berisha, C. Combellas, F. Kanoufi, J. Pinson, S. Ustaze, F. I. Podvorica, Indirect Grafting of Acetonitrile Derived Films on Metallic Substrates, Chem. Mater. 22, 2962-2969 (2010).

[11] a) S. A. Refaey, F. Taha, A. Abd El-Malak, Inhibition of stainless steel pitting corrosion in acidic medium by 2-mercaptobenzoxazole, Appl. Surf. Sci., 236, 175-185 (2004). b) X. Li, S. Deng, H. $\mathrm{Fu}, \mathrm{G} . \mathrm{Mu}$, Inhibition effect of 6-benzylaminopurine on the corrosion of cold rolled steel in $\mathrm{H}_{2} \mathrm{SO}_{4}$ solution, Corros. Sci, 51, 620-634 (2009). c) P. C. Okafor, X. Liu, Y. G. Zheng, Corrosion inhibition of mild steel by ethylamino imidazoline derivative in $\mathrm{CO}_{2}$-saturated solution, Corros. Sci., 51, 761-768 (2009).

[12] G. Gece, The use of quantum chemical methods in corrosion inhibitor studies, Corros. Sci., 50, 29812992 (2008).

[13] H. Ashassi-Sorkhabi, B. Shabani, D. Seifzadeh, Corrosion inhibition of mild steel by some Schiff base compounds in hydrochloric acid, Appl. Surf. Sci., 239, 154-164 (2005).

[14] H. Ashassi-Sorkhabi, B. Shabani, D. Seifzadeh, Effect of some pyrimidinic Schiff bases on the corrosion of mild steel in hydrochloric acid solution, Electrochem. Acta, 50, 3446-3452 (2005).

[15] S. A. Umoren, I. B. Obot, E. E. Ebenso, N. O. ObiEgbedi, The Inhibition of aluminum corrosion in hydrochloric acid solution by exudate gum from Raphia hookeri, Desalination, 247, 561-572 (2009).

[16] R. M. Issa, M. K. Awad, F. M. Atlam, Quantum chemical studies on the inhibition of corrosion of copper surface by substituted uracils, Appl. Surf. Sci., 255, 2433 (2008).

[17] M. M.Kabanda, L. C. Murulana, E. E. Ebenso, Theoretical studies on phenazine and related compounds as corrosion inhibitors for mild steel in sulfuric acid medium, Int. J. Electrochem. Sci., 7, 7179-7205 (2012).

[18] K. F. Khaled, Molecular simulation, quantum chemical calculations and electrochemical studies for inhibition of mild steel by triazoles, Electrochem. Acta, 53, 3484-3492 (2008).

[19] B. Gomez, N. V. Likhanova, M. A. DominguezAguilar, R. Martinez-Palou, A. Vela, J. L. Gazquez, Quantum Chemical Study of the Inhib- 
itive Properties of 2-Pyridil-Azoles, J. Phys. Chem. B, 110, 8928-8934 (2006).

[20] P. Geerlings, F. De Proft, W. Langenaeker, Conceptual density functional theory, Chem. Rev., 103, 1793-1874 (2003).

[21] Pauling, L. The Nature of the Chemical Bond and the Structure of Molecules and Crystals: An Introduction to Modern Structural Chemistry, Cornell University Press, 1960.

[22] P. Senet, Chemical hardness of atoms and molecules from frontier orbitals, Chem. Phys. Lett., 275, 527-532 (1997).

[23] J. B. Foresman, A. Frisch, Exploring Chemistry with Electronic Structure Methods, Gaussian, Inc., Pittsburgh, PA, 1996.

[24] J. O’M. Bockris, B. Yang, The mechanism of corrosion inhibition of iron in acid solution by acetylenic alcohols, J. Electrochem. Soc., 138, 2237-2252 (1991).

[25] I. B. Obot, N. O. Obi-Egbedi, Anti-corrosive properties of xanthone on mild steel corrosion in sulfuric acid: Experimental and theoretical investigations, Curr. Appl. Phys., 11, 382 (2011).

[26] C. Cao, On electrochemical techniques for interface inhibitor research, Corros. Sci., 38, 20732082 (1996).

[27] N. O. Eddy, Experimental and theoretical studies on some amino acids and their potential activity as inhibitors for the corrosion of mild steel, part 2, $\mathrm{J}$. Adv. Res., 2, 35-47 (2011).

[28] N. O. Eddy, F. E. Awe, C. E. Gimba, N. O. Ibisi, E. E. Ebenso, QSAR, Experimental and computational chemistry simulation studies on the inhibi- tion potentials of some amino acids for the corrosion of mild steel in $0.1 \mathrm{M} \mathrm{HCl}$, Int. J. Electrochem. Sci., 6, 931-957 (2011).

[29] K. F. Khaled, M. A. Amin, Corrosion monitoring of mild steel in sulfuric acid solutions in presence of some thiazole derivatives - Molecular dynamics, chemical and electrochemical studies, Corros. Sci., 51, 1964-1975 (2009).

[30] A. S. Fouda, A. S. Ellithy, Inhibition effect of 4phenylthiazole derivatives on corrosion of 304L stainless steel in $\mathrm{HCl}$ solution, Corros. Sci., 51, 868-875 (2009).

[31] A.Yurt, S. Ulutas, H. Dal, Electrochemical and theoretical investigation on the corrosion of aluminum in acidic solution containing some Schiff bases, Appl. Surf. Sci., 253, 919-925 (2006).

[32] N. O. Obi-Egbedi, I. B. Obot, M. I. El-Khaiary, Quantum chemical investigation and statistical analysis of the relationship between corrosion inhibition efficiency and molecular structure of xanthenes and its derivatives on mild steel in sulfuric acid, J. Mol. Struct., 1002, 86-96, (2011).

[33] L. M. Rodriguez-Valdez, W. Villamisar, M. Casales, J. G. Gonzalez-Rodriguez, A. MartinezVillafane, L. Martinez, D. Glossman-Mitnik, Computational simulations of the molecular structure and corrosion properties of amidoethyl, aminoethyl and hydroxyethyl imidazolines inhibitors, Corros. Sci., 48, 4053-4064 (2006).

[34] A. Maniavel, S. Ramkumar, J. J. Wu, A. M. Asiri, S. Anandan, Exploration of (S)-4,5,6,7-tetrahydrobenzo $[d]$ thiazole-2,6-diamine as feasible corrosion inhibitor for mild steel in acidic media, J. of Environ. Chem. Eng., 2, 463-470 (2014). 